\title{
Research on the Teaching Reform of "Course-based Ideological and Political Education" in College Physical Education
}

\author{
Yuci Wang \\ Beijing University of Agriculture, \\ Beijing, 102206
}

\begin{abstract}
The "Course-based Ideological and Political Education" in college physical education is necessary to deepen the teaching reform of physical education and ideological and political education. Aiming at the necessity and feasibility of “Course-based Ideological and Political Education" in college physical education, the author explored the main measures, which includes strengthening the construction of the physical course, enriching sports methods, enhancing physical teachers' related quality and ability, and establish scientific and rational assessment system. These measures can help realize the organic combination of college physical education and ideological and political education, and provide references for the teaching reform of "Course-based Ideological and Political Education" in college physical education.
\end{abstract}

Keywords-college; physical education; “Course-based Ideological and Political Education"; ideological and political education

\section{INTRODUCTION}

College ideological and political education is systematic and complex, which refers to strengthening the related teaching, improving related effects, and establishing a training concept featuring all aspects and dimensions. In the 2016 national college ideological and political work conference, President $\mathrm{Xi}$ Jinping stressed that ideology and politics is supposed to be integrated with the whole process of teaching to achieve training talents in the whole process and from all aspects. In addition, in order to take advantage of the main channel of classroom teaching, all other courses should take their own responsibility to make sure that all courses keep up with ideological and political course and the coordinated effect can be formed. Therefore, it is a must for deepening the teaching reform of college education to establish the concept of "Course-based Ideological and Political Education", organically integrate general courses and professional courses with ideological and political courses, and dig out the related resources of all kinds of courses. As the compulsory public course for all college students, physical course should help students build up their strong bodies, promote their harmonious mind and body, and train their good quality and literal spirit. The integration of "Course-based Ideological and Political Education” with sports class is of great significance to realize the talent training of physical course.

\section{THE NECESSITY AND FEASIBILITY OF IMPLEMENTING “COURSE-BASED IDEOLOGICAL AND POLITICAL EDUCATION” IN PHYSICAL COURSE}

A. The physical course is a significant method to implement ideological and political education

In order to implement the "Course-based Ideological and Political Education”, it is necessary to break through the boundary among general course, professional course, and ideological and political course, and find out their overlapping points. The physical course has special advantages in ideological and political education. Mr. Cai Yuanpei once said that physical education is key to train a sound talent. The physical course can help students build up their bodies, promote their overall development, and train their good and comprehensive qualities. And its skill practicing, knowledge learning, personality shaping and quality training are corresponding with the training objectives of ideological and political education. The characteristic of confrontation and culture, the spirit of competition, and awareness of rules make it possible for the physical course to provide abundant material and spiritual resources for ideological and political education, and it also makes it possible to implement "Course-based Ideological and Political Education” in the physical course. [1]

Its strong practice and appeal make it the significant carrier for ideological and political course. Students can gain direct emotional experience from sports training and competition which integrates teaching with entertainment, and they can know more about the functions of moral education and accept them. Such method of promoting moral education in sports can help students have the same feeling from their own participation and experience, deepen their understanding with ideological concepts and values. The effect is far more persuasive and appealing than mere theory teaching.

\section{B. “Course-based Ideological and Political Education” in physical education is urgent in deepening the teaching reform of physical education}

There are some prominent problems in the current college physical education. In terms of teaching concepts, physical skill training and standard grades are regarded as the most important, which has made physical course a kind of dull and single sports training, severely ignoring the true connotation of 
sports. Most colleges fail to pay enough attention to physical course, not treating physical course and professional course equally. As a result, students' sports grades are neglected in the assessment and comprehensive ranking. In addition, sports teachers' teaching and research abilities can't be highlighted, which leads to some teachers' lacking enthusiasm about teaching. What's more, students lower their requirements with sports grades. In terms of teaching content, it emphasizes outdoor sports training rather than classroom theory teaching, skill training rather than sports culture and history teaching, the standard of velocity and strength rather than solidarity, cooperation and spirit of competition. So the teaching content fails to fully express the true charm of sports, not good for the development of students' bodies and minds as well as their comprehensive qualities. [2]

\section{C. "Course-based Ideological and Political Education" in physical education is the need for deepening the teaching reform of ideological and political education}

College ideological and political education aims to teach students the standpoints, viewpoints and methods of Marxism, help them establish a correct outlook on the world, life and value, and train and practice socialist core values. [3]Current ideological and political education regards the ideological and political course as the main channel, paying more attention to theory teaching than practice and neglecting the real needs of students. Besides, its form lacks innovation, and teaching content fails to closely connect with social culture and reality, which cannot draw students' attention. Ideological and political education is viewed as the task of related teachers, while other teachers cannot take full advantage of the implicit teaching resource and focus on students' ideological and political education. Integrating ideological and political education with other courses and work is important for teaching reform of ideological and political education. In the 2017 meeting with national advanced sports units and individuals representatives, President Xi Jinping stressed that we should regard meeting national fitness demands and promoting the comprehensive development as the starting point and objective. Strengthening the ideological and political work needs to reform and innovate college ideological and political education, while it needs to implement "Course-based Ideological and Political Education" and push all kinds of courses to integrate with ideological and political education. Physical course, as the compulsory course for all college students, regards promoting the comprehensive development of students as its starting point and objective, which is corresponding with the target of ideological and political education. Therefore, to implement the "Course-based Ideological and Political Education" in physical education is the need of deepening the teaching reform of ideological and political education.

D. To implement the "Course-based Ideological and Political Education" is the need of realizing the teaching objective of the physical course

Physical education is an important part of higher education, so integrating ideological and political education with sports teaching can meet the demand of realizing the teaching objective of college physical education, and the urgent demand of implementing quality education and promoting students' comprehensive development. The teaching objective of college physical education includes sports participation, sports skills, physical health, mental health and social adaptation. Among them, the first three are the requirements for students' physical health, sports skills and knowledge, and its focus is training students' good physical quality and improving their sports skills. However, the latter two are about students' mental health, patriotism, collectivism and social awareness, and the focus is on training students' good mental qualities. [4]In order to realize these goals, students' willpower and courage should be trained. Then, students' awareness of fair competition, solidarity and cooperation should be cultivated. Thirdly, students' good sports morality should be emphasized to possess patriotism and collectivism. All of these are corresponding with the socialist core values of "patriotism, devotion, honesty and friendship" and correct outlook on the world, life and value. The implementation of "Course-based Ideological and Political Education" can represent the correspondence of the objective of physical education and ideological and political education, as well as the requirements of the physical course.

\section{EXPLORATION OF THE TEACHING REFORM OF "COURSE- BASED IDEOLOGICAL AND POLITICAL EDUCATION” IN COLLEGE PHYSICAL EDUCATION}

\section{A. Strengthening the construction of the physical course, and teaching content should represent the ideological and political education}

Various sports events should be connected to optimize course construction. And all kinds of sports training and activities can be used to integrate ideological and political education resource with sports teaching.

1) To carry out ideological and political education in combination with track and field events

Track and field events include running, jumping, race walking and throwing. They can help people comprehensively develop their physical quality, increase their strength, velocity, stamina, sports grades and skills, and make them more tenacious and resolute. Students can become more hardworking and persevering based on the long-running, which can help realize the goal of ideological and political education.

2) To carry out ideological and political education in combination with ball games

Ball games refer to basketball, volleyball, football, badminton and tennis. All of them are featuring confronting, massive and social. And they can help train students' abilities of coordination, judgment and sports, and cultivate their spirit of teamwork and awareness of collectivism. For example, basketball is of entertainment, competition and cooperation, and it can make students more positive, brave, cooperating and tenacious, and strengthen their collective sense of honor. Due to its confrontation, students can train their discipline, tenacity, cohesion and coordination, and become calm and resolute. In addition, the result of the competition can be used by ideological and political education. The good result can 
promote them to be more solitary; otherwise, the team spirit can inspire them to train their willpower and guide them to face difficulties with a good state, rationally analyze problems, find out the methods to defeat the failure and shape their sound personality.

3) To carry out ideological and political education in combination with traditional ethnic sports

Traditional ethnic sports include taijiquan, dragon boat racing, lion dancing, martial arts, taekwondo and so on. These sports activities pay attention to the combination of body and mind, sports education and moral and aesthetics education, which can refresh students' spirit and relax their minds. Students' physical quality and cultural awareness can be strengthened. And in practical training, they can deepen students' understanding and experience with traditional sports culture. They are the integration of entertainment, fitness and education. [5]For instance, martial art has a long history, and it can promote students' overall development of morality, intelligence, body and aesthetics. Traditional ethnic sports originate from folk traditions, customs and habits, through which students can train their spirit of solidarity and positiveness, promote their own comprehensive development, inherit excellent traditional sports culture, and train their cultural confidence and patriotism.

\section{B. Enriching the modes of sports and penetrate the spirit of ideological and political education}

Besides regular classroom teaching, college physical education includes morning exercise, training, clubs, competitions and extracurricular activities. Physical course allows students to widely and happily participate in when they are free. So the characteristic should be combined with the entertaining sports activities to increase the covering area of ideological and political education. Firstly, sports team should be positively used to popularize sports culture and guide students to participate in physical exercise, know about the connotation of physical education, experience its charm and train their awareness of life-long sense on sports. For example, Beijing University of Agriculture set up the team of football, basketball, volleyball, golf, swimming, track and field, tennis, orienteering, and traditional health, all of which represent the college to participate in various sports competitions, and give full play to their advantages to attract more students to the physical exercise. Secondly, it is necessary to carry out massive sports activities. Since 2014, the Central Committee of the Communist Young League has launched the massive extracurricular sports activity themed by "off the network, step out from the dormitory towards the playground". In order to realize the further development of sunshine sports activity, Beijing University of Agriculture established all kinds of sports clubs like volleyball, basketball, football, tennis, golf, badminton, orienteering, aerobics and quality development. These sports clubs play a leading role in implementing the activity spirit. And in order to guide and monitor the club to positively launch activities, Beijing University of Agriculture set up the working group of sunshine sports, and established assessment system based on the points that students can get according to the activity implementation, which can encourage students to actively participate in sports exercise. The massive sports activity can help students strengthen their bodies and faith, combine the activity spirit of "three walks" with healthy lifestyle, and give full play to the positive function of sports in training students' comprehensive quality and personablity.

\section{Improving physical teachers' quality and ability of "Course-based Ideological and Political Education"}

Firstly, physical teachers should teach physical theories and sports skills, and train and practice socialist core values. However, physical teachers just pay attention to practical training rather than the learning of ideological and political theories. Therefore, physical teachers must strengthen their learning with Marxist theories and ideological and political theory level. Their training can connect with social reality, hot spots and ideological and political theories. Secondly, improve teachers' personal quality and literary accomplishment. In physical teaching, integrating excellent traditional Chinese culture with sports culture requires teachers to have abundant knowledge and high comprehensive quality. Thirdly, physical course is of strong practice. Different physical projects give people different feelings. And the goals of ideological and political education vary from each other, too. Therefore, physical teachers" ability of implementing “Course-based Ideological and Political Education" should be strengthened. Specifically, one to two ideological and political teachers can be sent to the sports group so that they can jointly formulate the teaching syllabus for physical course, and discuss the related elements in physical teaching. Then, physical teachers can use effective teaching methods based on different sports events and make physical course more interesting and charming.

\section{Establishing a scientific and rational assessment system and connect with the standards of ideological and political education}

Even though college physical course has been always emphasizing "fostering the morality training", the function of moral education is always been neglected. The main reason is that physical teaching assessment has clear assessment system with students' body quality test and skill standard, but fails to have relevant evaluation criteria with ideological and political education. So the function of ideological and political education is weakened in physical teaching. In order to realize the function of "Course-based Ideological and Political Education" in physical education, it is a must to establish scientific and rational assessment system and integrate ideological and political education standard with it. In terms of the management department of higher education, they should strategically arrange and coordinate all sectors to establish the evaluation system for the ideological and political teaching in college physical course. College leaders should pay great attention to it, and order teachers to teach according to the assessment standards by making the standards detailed. In addition, they should emphasize the ideological and political education in physical teaching and positively dig out related elements in physical teaching. [3]The working performance of physical teachers participating in "Course-based Ideological and Political Education" can be regarded as a significant basis for annual assessment and position promotion so that the 
“Course-based Ideological and Political Education” can be put into practice.

\section{CONCLUSION}

“Course-based Ideological and Political Education” in college physical education is the need for deepening the teaching reform of physical education and ideological and political education. In order to realize the teaching reform of "Course-based Ideological and Political Education", it is necessary to strengthen physical course construction, enrich sports modes, improve physical teachers' quality and ability to implement "Course-based Ideological and Political Education", and establish scientific and rational assessment system. “Course-based Ideological and Political Education” in college physical education is still in the stage of exploration, which needs further research and proving in theory, and the further implementation in practice.

\section{REFERENCES}

[1] Chang Yi and Zhang Shu. The soul of sports: Research on the ideological and political education of college physical course[J]. Sports Culture Guide,2018 (6): 136-141.

[2] Feng Li. Research on the ways of integrating the concept of "Coursebased Ideological and Political Education” into physical course[J]. School Physical Education,2018,8(29): 78-79.

[3] Zhu Xiaoling. An analysis of the integration of public physical course and ideological and political education in ordinary colleges[J]. Neijiang Technology,2017,38(11): 75-76,53.

[4] Pan Hongbo and Huang Dazhi. Discussion on the ideological and political education of college public physical course[J]. School Physical Education,2018 8(17): 78-79.

[5] Huang Qiang and Gai Dongpeng. Research on the collaborative education of physical course from the perspective of "the great Coursebased Ideological and Political Education”[J]. Stationery and Technology,2018 (11): 41-42. 